\title{
Determinan Komplikasi Kronik Diabetes Melitus pada Lanjut Usia
}

\author{
Determinan of Diabetes Mellitus Chronic Complications on Elderly
}

\author{
Amrina Rosyada, Indang Trihandini
}

Departemen Biostatistika dan Ilmu Kependudukan Fakultas Kesehatan Masyarakat Universitas Indonesia

\begin{abstract}
Abstrak
Indonesia menghadapi jumlah penduduk lanjut usia (lansia) yang semakin meningkat dan diikuti oleh peningkatan frekuensi penyakit tidak menular kronis atau multimorbiditas. Penelitian ini bertujuan untuk mengetahui prevalensi dan faktor yang berhubungan komplikasi kronis pada lansia penderita diabetes melitus. Penelitian ini menggunakan data Riset Kesehatan Dasar (Riskesdas) Tahun 2007 dengan desain cross sectional representatif Indonesia dan metode cluster 2 tahap untuk pengambilan sampel. Sampel adalah 1.565 lansia penderita diabetes melitus. Metode analisis yang digunakan meliputi analisis deskriptif dan multivariat. Hasil analisis menunjukkan bahwa prevalensi komplikasi kronis pada lansia adalah sekitar $73,1 \%$, dengan hipertensi sebagai komplikasi terbanyak. Berdasarkan analisis multivariat diketahui pula bahwa faktor-faktor yang berhubungan dengan komplikasi diabetes adalah usia, jenis kelamin, obesitas, merokok, dan aktivitas fisik dan faktor utama yang berhubungan adalah merokok (OR = 2,48). Hasil penelitian menyarankan program untuk mencegah kesakitan dan komplikasi diabetes pada lansia perlu ditingkatkan. Saat ini program Kementerian Kesehatan Republik Indonesia yaitu CERDIK meliputi cek kesehatan secara berkala, enyahkan asap rokok, rajin berolahraga, diet sehat kalori seimbang, istirahat yang cukup dan kendalikan stres perlu diperluas.
\end{abstract}

Kata kunci: Diabetes, komplikasi kronis, lansia

\section{Abstract}

Indonesia faces a growing number of elderly people is increasing, with increasing elderly, not infectious diseases increase chronic or multimorbidity, there by the study has aims to explore the prevalence of Chronic Complications on elderly with diabetes mellitus and related factors. The research used data from National Basic Health Research 2007. National Basic Health Research is a cross-sectional design survey, two stage cluster method for sampling. The result is shown that the prevalence of chronic complication on the elderly with diabetes mellitus is $73.1 \%$. Hypertension disease is the most of chronic complication that has been frequent appeared on elderly with diabetes mellitus. Based on multivariate analysis revealed to diabetes mellitus complication related with age, gender, obesity, smoking, and physical activity. The study purposes to emphasize of prevention and promotion program such as CERDIK program from Ministry of Health, Republic of Indonesia. The CERDIK program has many intervention programs, for example, reducing smoking, delegating regularly exercise, balancing healthy-diet calorie, resting and taking control of stress.

Keywords: Diabetes, complications chronic, elderly

\section{Pendahuluan}

Angka rata-rata harapan hidup penduduk di dunia telah meningkat secara drastis. Saat ini, di Indonesia, proporsi lanjut usia (lansia) yang berusia di atas 90 tahun diperkirakan mencapai $1,2 \%$ dari total penduduk. Jumlah tersebut telah meningkat $400 \%$ dari sensus tahun 1990. Angka harapan hidup orang tertua di dunia mencapai 115 tahun pada wanita dan pada pria lebih singkat. ${ }^{1}$ Peningkatan ini berdampak pada transisi epidemiologi, yang memperlihatkan penurunan prevalensi penyakit infeksi dan menular bersamaan dengan peningkatan angka penyakit tidak menular pada penduduk dewasa dan lanjut usia. ${ }^{2}$ Setiap tahun, angka harapan hidup penduduk Indonesia terus meningkat, pada tahun 2010, jumlah penduduk usia di atas 60 tahun mencapai 20,7 juta orang, kemudian menjadi 36 juta orang. Kenaikan tersebut diprediksi akan terus bertambah hingga mencapai 71 juta orang pada tahun 2050. Jumlah pen-

Alamat Korespondensi: Indang Trihandini, Departemen Biostatistik dan Ilmu Kependudukan FKM Universitas Indonesia Gd. A Lt. 2, Kampus Baru UI Depok 16424,Hp.08121035617,e-mail:dini05@ui.ac.id 
duduk lansia yang semakin meningkat tersebut, menjadi tantangan baru bagi Indonesia, begitu pula dengan peningkatan lansia yang mengalami berbagai penyakit tidak menular kronis atau multimorbiditas. ${ }^{2}$

Kenaikan angka harapan hidup merupakan prestasi dan mengindikasikan kemajuan pelayanan kesehatan yang diberikan. ${ }^{3}$ Namun, hal tersebut harus diimbangi dengan peningkatan pelayanan kesehatan yang memadai khususnya lansia. Penyakit akibat proses penuaan diikuti dengan penyakit tidak menular kronis yang menyerang para lansia akan menambah beban penduduk serta menurunkan kualitas hidup lansia. ${ }^{4}$ Menderita berbagai penyakit kronis dapat mengakibatkan kualitas hidup lansia yang buruk, lebih lama tinggal di rumah sakit, dapat mengalami komplikasi yang lebih parah pascaoperasi, biaya perawatan yang lebih tinggi, dan mortalitas yang lebih tinggi. ${ }^{5}$

Komplikasi kronis didefinisikan sebagai kondisi kronis yang memunculkan dua atau lebih penyakit, dengan salah satu penyakit tidak selalu lebih sentral daripada yang lain. Komplikasi kronis dapat memengaruhi kualitas hidup, kemampuan untuk bekerja, kecacatan dan kematian.5,6 Data komplikasi kronis pada lansia di Bangladesh, sebagai salah satu negara berkembang mencapai angka $53,8 \%$, lebih banyak terjadi pada perempuan dan kelompok sosial ekonomi rendah. Penelitian yang sama dilakukan di Swedia menghasilkan prevalensi yang tidak jauh berbeda yaitu $54,8 \%$ dengan hipertensi, demensia, dan gagal jantung sebagai gangguan tersering. ${ }^{6}$ Data dan informasi mengenai komplikasi kronis di Indonesia masing kurang. Padahal, data ini penting untuk menggambarkan kualitas hidup penduduk lanjut usia di Indonesia karena pada hakikatnya, penduduk lanjut usia tetap mempunyai hak penuh untuk hidup sehat dan tetap produktif di masa tua. Selain itu, penduduk lansia yang sehat akan mengurangi beban keluarga dan masyarakat. ${ }^{7}$

Diabetes melitus merupakan salah satu penyakit kronis yang dapat meningkatkan dengan cepat prevalensi komplikasi kronis pada lansia. Hal ini disebabkan kondisi hiperglikemia akibat ketiadaan absolut insulin atau penurunan relatif sensitivitas sel terhadap insulin, akan memicu munculnya penyakit tidak menular kronis lainnya, bahkan kematian penyandang diabetes melitus tidak jarang disebabkan oleh komplikasi. ${ }^{8,9}$ Klub Persadia Rumah Sakit Islam Jakarta Pondok Kopi Tahun 1998 - 2005 menjelaskan bahwa komplikasi diabetes terbanyak adalah hipertensi dengan proporsi sekitar $54,2 \% .10$

Prevalensi diabetes melitus yang terdiagnosis pada penduduk usia di atas 65 tahun menurut data Riskesdas tahun 2007 adalah 4,6\%. Diabetes melitus pada lansia seringkali tidak disadari karena gejala-gejala diabetes seperti sering haus, sering berkemih, dan penurunan berat badan tersamarkan akibat perubahan fisik alamiah lansia yang mengalami penurunan, sehingga diabetes yang tidak terdiagnosis ini akan terus berkembang menjadi komplikasi yang dapat berakibat fatal. ${ }^{11,12}$ Data di Rumah Sakit Umum Daerah (RSUD) dr. H. Abdul Moeloek Provinsi Lampung menunjukkan angka prevalensi diabetes melitus mencapai $35,5 \%$ dengan $76,2 \%$ mengalami komplikasi. ${ }^{13}$ Poli lansia puskesmas kecamatan Jatinegara juga menunjukkan angka prevalensi diabetes melitus yang tak jauh berbeda yaitu mencapai $29,3 \%$ pada lansia usia $60-69$ tahun dan $20,8 \%$ pada lansia usia $\geq 70$ tahun. ${ }^{14}$

Diabetes melitus sebagian besar disebabkan oleh faktor genetik dan perilaku atau gaya hidup seseorang. Selain itu, faktor lingkungan sosial dan pemanfaatan pelayanan kesehatan juga berkontribusi terhadap kesakitan diabetes melitus dan komplikasinya. ${ }^{15}$ Diabetes dapat memengaruhi berbagai organ sistem dalam tubuh dalam jangka waktu tertentu yang disebut komplikasi. Komplikasi dari diabetes dapat diklasifikasikan sebagai mikrovaskuler dan makrovaskuler. Komplikasi mikrovaskuler termasuk kerusakan sistem saraf (neuropati), kerusakan sistem ginjal (nefropati) dan kerusakan mata (retinopati). Sedangkan, komplikasi makrovaskular termasuk penyakit jantung, stroke, dan penyakit pembuluh darah perifer. Penyakit pembuluh darah perifer dapat menyebabkan cedera yang sulit tidak sembuh, gangren, bahkan amputasi. Komplikasi yang lain termasuk kerusakan gigi, penurunan resistensi infeksi seperti influenza dan pneumonia, makrosomia dan komplikasi saat melahirkan. ${ }^{9}$ Komplikasi penyakit ini dikategorikan serius sehubungan dengan kemunculan penyakit kronis lain yang berbahaya seperti penyakit jantung, hipertensi, stroke, kebutaan akibat retinopati, glaukoma, katarak, gagal ginjal, impotensi pada pria serta kecacatan akibat luka yang sulit disembuhkan. Sekitar $83,3 \%$ penyandang diabetes melitus tipe dua yang dirawat di unit rawat inap RSUD Pasar Rebo mengalami komplikasi, dan pada lansia (> 60 tahun) komplikasi tersebut sekitar 94,6\%. Pada usia lanjut, risiko diabetes melitus akan meningkat sehingga termasuk kelompok yang rentan terhadap kondisi ini. ${ }^{16,17,18}$

Kondisi komplikasi kronis dapat menjadi ancaman buruk bagi Indonesia karena pengobatan yang tidak dilakukan secara terintegrasi dapat memunculkan masalah baru yaitu multiuse of prescription atau polypharmacy. 19 Penggunaan sejumlah obat bersamaan mempunyai risiko seperti peningkatan reaksi obat, kepatuhan penggunaan yang sulit diterapkan, serta peningkatan insiden efek obat yang tidak diharapkan. Selain itu, lanjut usia membuat farmakokinetik yang disebabkan berkurangnya kapasitas untuk metabolisme obat dan aspek farmakodinamik dalam tubuh, sehingga akan meningkatkan risiko terjadi reaksi toksik. Oleh karena itu, penggunaan obat secara 
bersamaan pada orang tua harus dibatasi. ${ }^{20,21}$ Pelayanan kesehatan lansia bertujuan mengantarkan mereka melintasi usia lanjut dalam keadaan sehat, berbahagia, produktif dan mandiri. 22 Dengan menyediakan pelayanan kesehatan yang memadai berarti memberikan perlindungan, penghormatan, pemajuan, dan penghargaan lanjut usia. ${ }^{7}$

Perwujudan pelayanan lansia yang memadai di Indonesia masih bermasalah, mulai dari kepedulian tenaga kesehatan dan pemerintah, pembiayaan, hingga sarana prasarana publik yang belum memadai. Pelayanan kesehatan lansia yang buruk tersebut semakin terlihat di daerah pedesaan. ${ }^{19}$ Padahal pada kenyataannya, pengelolaan orang lanjut usia di Indonesia ditangani Subdirektorat Bina Pelayanan Kesehatan Khusus, Usia Lanjut dan Pelayanan Darah, Kementerian Kesehatan Republik Indonesia serta Direktorat Pelayanan Sosial Lanjut Usia, Kementerian Sosial Republik Indonesia. ${ }^{23}$ Selain itu, terdapat pula Peraturan Pemerintah Nomor 43 Tahun 2004 tentang Pelaksanaan Upaya Peningkatan Kesejahteraan Lanjut Usia. Upaya tersebut mencakup pelayanan keagamaan, mental, spiritual, pelayanan kesehatan dan pelayanan umum serta kemudahan dalam penggunaan fasilitas umum bagi lansia.

Penelitian ini bertujuan untuk mengetahui prevalensi, pola kombinasi penyakit komplikasi kronis penyandang diabetes melitus, dan faktor yang berhubungan dengan penyakit komplikasi kronis diabetes pada lansia pengidap diabetes melitus di Indonesia, sehingga dapat diestimasi jumlah, jenis, dan kualitas pelayanan kesehatan lansia yang perlu ditingkatkan untuk meningkatkan kualitas hidup penduduk lansia dengan jumlah yang terus meningkat.

\section{Metode}

Desain penelitian ini adalah cross sectional dengan menggunakan data sekunder Riskesdas tahun 2007 oleh Badan Penelitian dan Pengembangan Kesehatan Kementerian Kesehatan Republik Indonesia. Populasi pada penelitian ini adalah seluruh penduduk lanjut usia di Indonesia. Sampel penduduk lanjut usia $(\geq 60$ tahun) yang tercatat pada data Riskesdas 2007 dan memenuhi kriteria inklusi dan eksklusi. Kriteria inklusi adalah lansia berusia $\geq 60$ tahun, mengidap diabetes melitus berdasarkan diagnosis tenaga kesehatan. Kriteria eksklusi adalah lansia dengan indeks massa tubuh di bawah 18,5, menderita penyakit jantung bawaan dan data tidak lengkap. Sampel yang memenuhi kriteria inklusi dan ekslusi adalah 1.565 sampel. Pada studi ini tidak dapat dilihat penyakit nefropati diabetes, retinopati diabetes, dan penyakit arteri perifer karena data tidak tersedia. Analisis data dilakukan menggunakan bantuan perangkat lunak pro- gram statistik. Analisis yang akan dilakukan meliputi analisis univariat deskriptif kuantitatif.

Pada studi ini, peneliti akan mengamati variabel kelompok umur, jenis kelamin, status kawin, status sosial ekonomi, tingkat pendidikan, indeks massa tubuh, status merokok, konsumsi lemak, konsumsi sayur dan buah, aktivitas fisik, dan pemanfaatan pelayanan kesehatan serta status penyakit komplikasi kronis diabetes melitus. ${ }^{5}$ Hubungan atau asosiasi antara variabel independen dan satu variabel dependen akan diuji dengan kai kuadrat dengan $\alpha=5 \%$. Analisis multivariat menggunakan regresi logistik dengan model prediksi dan $\alpha=5 \%$. Uji interaksi dilakukan antara variabel merokok dan jenis kelamin untuk mendapatkan model multivariat yang sahih.

Komplikasi kronis diabetes melitus didefinisikan sebagai kondisi seseorang mengidap dua atau lebih penyakit atau kondisi kronis, dengan diabetes melitus dianggap sebagai penyakit sentral, dan penyakit atau kondisi kronis lain adalah penyakit kronis hasil komplikasi dari penyakit sentral. Penyakit kronis akibat komplikasi diabetes antara lain adalah hipertensi, penyakit jantung koroner, katarak, dan stroke. Responden dikategorikan mengalami penyakit komplikasi kronis diabetes adalah responden yang mengidap diabetes dan mengidap minimal satu penyakit kronis lain. Sedangkan non komplikasi kronis adalah responden yang hanya mengidap diabetes melitus.

\section{Hasil}

Sebagian besar lansia pengidap diabetes melitus berada pada kelompok umur 60 - 74 tahun $(83,3 \%)$, berjenis kelamin perempuan $(52,9 \%)$, berstatus menikah $(67 \%)$, berasal dari sosial ekonomi rendah $(53,6 \%)$, berpendidikan rendah $(73,4 \%)$ dan berstatus gizi baik $(52,8 \%)$. Jika ditinjau dari faktor perilaku, sebagian besar lansia pengidap diabetes melitus mempunyai konsumsi sayur dan buah yang kurang $(99,4 \%)$, aktivitas fisik yang kurang $(97,5 \%)$, tidak sering mengonsumsi makanan berlemak $(92,2 \%)$, dan bukan perokok $(63,2 \%)$. Selain itu, diperoleh pula informasi bahwa sebagian besar lansia pengidap diabetes melitus yang mempunyai akses atau pemanfaatan yang baik terhadap pelayanan kesehatan $(57,8 \%)$. Lansia pengidap diabetes melitus yang

Tabel 1. Status Komplikasi Diabetes Melitus pada Lansia

\begin{tabular}{llc}
\hline Status Komplikasi Diabetes Melitus & Frekuensi & Persentase (\%) \\
\hline Non komplikasi kronis & 421 & 26,9 \\
Komplikasi kronis & 1.144 & 73,1 \\
\hline Total & $\mathbf{1 . 5 6 5}$ & $\mathbf{1 0 0 , 0}$ \\
\hline
\end{tabular}


Tabel 2. Jumlah Penyakit Komplikasi Diabetes Melitus yang Diderita

\begin{tabular}{llc}
\hline Status Komplikasi Kronis Diabetes Melitus & Frekuensi & Persentase (\%) \\
\hline Non komplikasi & 421 & 26,9 \\
Satu penyakit & 655 & 41,8 \\
Dua penyakit & 384 & 24,5 \\
Tiga penyakit & 94 & 6,0 \\
Empat penyakit & 11 & 0,7 \\
\hline Total & $\mathbf{1 . 5 6 5}$ & $\mathbf{1 0 0 , 0}$ \\
\hline
\end{tabular}

Tabel 3. Kombinasi Penyakit Komplikasi pada Lansia Pengidap Diabetes Melitus

\begin{tabular}{lc}
\hline Pola Komplikasi Diabetes Melitus & Persentase (\%) \\
\hline Diabetes dan hipertensi & 35,1 \\
Diabetes, hipertensi, dan katarak & 19,8 \\
Diabetes dan katarak & 18,0 \\
Diabetes, jantung, dan hipertensi & 7,0 \\
Diabetes, stroke, dan hipertensi & 3,9 \\
Diabetes dan jantung & 3,8 \\
Diabetes, jantung, katarak, dan hipertensi & 3,5 \\
Diabetes, katarak, stroke, hipertensi & 3,4 \\
Diabetes, jantung, dan katarak & 2,3 \\
Diabetes, jantung, stroke, dan hipertensi & 1,3 \\
Diabetes, jantung, stroke, katarak, dan hipertensi & 0,9 \\
Diabetes dan stroke & 0,4 \\
Diabetes, katarak, dan stroke & 0,3 \\
Diabetes, jantung, dan stroke & 0,2 \\
\hline Total & $\mathbf{1 0 0 , 0}$ \\
\hline
\end{tabular}

Tabel 4. Analisis Multivariat

\begin{tabular}{lcccc}
\hline Variabel & B & Nilai p & OR & CI 95\% \\
\hline (Intercept) & $-1,045$ & 0,028 & 0,352 & $0,139-0,890$ \\
Umur & 0,493 & 0,011 & 1,637 & $1,125-2,380$ \\
Gender & 0,761 & 0,000 & 2,140 & $1,509-3,033$ \\
Olahraga & 0,454 & 0,017 & 1,575 & $1,087-2,284$ \\
Obesitas & 0,262 & 0,019 & 1,300 & $1,047-1,614$ \\
Merokok & 0,907 & 0,000 & 2,477 & $1,545-3,972$ \\
Seks* Rokok & 0,818 & 0,010 & 2,266 & $1,224-4,195$ \\
\hline
\end{tabular}

mengalami komplikasi $(73,1 \%)$ (Tabel 1).

Tabel 2 menggambarkan status komplikasi lebih dirinci dengan banyaknya penyakit kronis yang diderita selain diabetes melitus. Persentase paling besar adalah lansia dengan satu penyakit komplikasi $(41,8 \%)$, diikuti oleh lansia dengan dua penyakit komplikasi $(24,5 \%)$, lansia dengan tiga penyakit komplikasi $(6 \%)$ dan lansia dengan 4 penyakit komplikasi sebesar $(0,7 \%)$.

Tabel 3 menggambarkan pola atau kombinasi penyakit kronis yang menyertai diabetes melitus pada lansia berdasarkan jumlah penyakit komplikasi yang benar diderita. Prevalensi tertinggi adalah lansia pengidap diabetes melitus dengan satu penyakit komplikasi, yaitu hipertensi.

Analisis bivariat dilakukan untuk memilih variabel kovariat yang dapat masuk pada model akhir atau analisis multivariat dilakukan analisis bivariat dengan kriteria nilai $p=0,25$ mendapatkan variabel umur, gender, tidak berolahraga, obesitas berhubungan dengan komplikasi kronis pada lansia diabetes melitus. Pada analisis multivariat, faktor yang berhubungan paling dominan dengan komplikasi diabetes melitus pada lansia adalah status merokok. Lansia penderita diabetes melitus yang merokok berisiko 1,64 kali lebih besar untuk mengalami komplikasi daripada lansia pengidap diabetes melitus yang tidak merokok setelah dikontrol oleh variabel jenis kelamin, sosial ekonomi, dan status merokok. Lansia pengidap diabetes melitus dengan jenis kelamin perempuan mempunyai risiko 2,14 kali lebih besar untuk mengalami komplikasi diabetes melitus dibandingkan lansia dengan jenis kelamin laki-laki. Lansia pengidap diabetes melitus yang tidak cukup olahraga atau aktivitas fisik mempunyai risiko 1,58 kali lebih besar untuk mengalami komplikasi diabetes melitus dibandingkan lansia yang cukup aktivitas fisik. Pengaruh merokok terhadap komplikasi diabetes melitus pada beda kategori jenis kelamin. Pengaruh rokok terhadap komplikasi diabetes melitus dihitung berdasarkan strata jenis kelamin. Pada jenis kelamin laki-laki, pengaruh merokok terhadap komplikasi diabetes melitus 1,72 kali lebih besar. Sedangkan pada jenis kelamin perempuan, merokok berisiko 2,47 kali lebih besar mengalami komplikasi dibandingkan laki-laki yang merokok (Tabel 4).

\section{Pembahasan}

Pada klasifikasi status komplikasi diabetes melitus, tidak semua penyakit komplikasi kronis disertakan seperti gagal ginjal, glaukoma, retinopati, impoten, gangren, dan tuberkulosis. Sehingga proporsi responden yang mengalami komplikasi dapat menjadi underestimate dari keadaan sebenarnya. Pemilihan penyakit kronis yang diteliti disesuaikan pada penyakit yang terdapat pada data sekunder Riskesdas tahun 2007 dan lebih diutamakan penyakit yang menggunakan tatalaksana obatobatan. Terdapat pula keterbatasan lain yaitu pada status kesakitan hipertensi dan diabetes tidak diketahui mana penyakit yang mendahului. Namun, pada penelitian ini hipertensi tidak dieksklusi karena berdasarkan beberapa penelitian seseorang yang mengidap diabetes melitus bersamaan dengan hipertensi berpotensi besar untuk terkena penyakit jantung, stroke, gagal ginjal, dan penyakit kronis lainnya. Melalui angka ini dapat diperkirakan seberapa baik kualitas hidup lansia khususnya lansia pengidap diabetes melitus di Indonesia. Pada pengukuran antropometri seperti berat badan, tinggi badan, tekanan sistolik, tekanan diastolik, dan pemeriksaan visus mata memungkinkan bias pengukuran. Bias ini dapat terjadi akibat kesalahan pada petugas, subjek, dan alat ukur yang digunakan. Selain itu, memungkinkan ter- 
jadi recall bias saat pengumpul data menanyakan riwayat menderita suatu penyakit berdasarkan diagnosis tenaga kesehatan. Recall bias yang memengaruhi adalah tidak ada catatan secara khusus kapan penyakit kronis tersebut mulai disandang.

Ancaman bias yang dapat terjadi juga yaitu bias seleksi. Berdasarkan data Riskesdas, jumlah sampel yang memenuhi kriteria inklusi yaitu berusia $\geq 60$ tahun dan mengidap diabetes melitus berdasarkan diagnosis tenaga kesehatan adalah 1.924 sampel, namun yang akan digunakan dalam penelitian ini sebanyak 1.565 sampel. Sejumlah 360 sampel dikeluarkan dari daftar responden yang diteliti karena terdapat data hilang pada variabelvariabel penting yang dibutuhkan sehingga karakteristik atau frekuensi dari variabel-variabel tertentu dapat hilang yang sebenarnya dapat memengaruhi hasil dari penelitian. Karakteristik dari 360 sampel tersebut adalah $52,5 \%$ perempuan, $62,5 \%$ berstatus kawin, $20 \%$ perokok, rata-rata umur 68 tahun, dan $28,6 \%$ berstatus obesitas, dan untuk variabel lainnya tidak dapat dilihat karakteristiknya karena banyak data yang mengalami missing. Gambaran karakteristik itu tidak memperlihatkan perbedaaan yang besar apabila dibandingkan dengan karakteristik pada studi ini.

Berdasarkan analisis deskriptif, lansia pengidap diabetes masih mempunyai perilaku yang kurang terhadap kesehatan terkait aktivitas fisik serta konsumsi sayuran dan buah-buahan yang kurang. Hal tersebut merupakan kontribusi pendidikan lansia dan status ekonomi yang masih tergolong rendah. Hasil tersebut hampir sama dengan laporan survei sosial ekonomi pada Juli 2009 yang mengindikasikan perubahan kecil pada perilaku kesehatan yang dicapai pada penduduk lansia. Berdasarkan laporan Riskesdas 2007, sekitar 4,6\% lansia yang mengidap diabetes melitus yang terdiagnosis. Jika pada tahun 2050, jumlah lansia di Indonesia mencapai 71 juta jiwa, ada sekitar 3 juta lebih lansia yang menderita diabetes melitus dan jika tidak ada upaya dan perubahan perilaku pencegahan, sekitar 2,5 juta akan mengalami komplikasi diabetes.

Kekhawatiran berhubungan dengan diabetes yang tidak terdiagnosis, mengingat diabetes melitus pada lansia sering tidak disadari karena gejala-gejala diabetes yang samar seperti sering haus, sering berkemih, dan penurunan berat badan akibat perubahan fisik alamiah lansia yang mengalami penurunan. Dengan demikian, diabetes yang tidak terdiagnosis tersebut akan terus berkembang menjadi komplikasi yang dapat berakibat fatal. ${ }^{11,12}$ Apabila diagnosis diabetes telah ditegakkan khususnya diabetes tipe 2 , sekitar $20 \%$ pasien sudah mengalami kerusakan retina, $8 \%$ mengalami disfungsi ginjal, dan $9 \%$ mengalami gejala neurologik. ${ }^{8}$ Dengan demikian, diagnosis diabetes melitus yang terlambat ditegakkan menyebabkan berbagai kerusakan yang terjadi sulit untuk dapat dicegah.

Hipertensi merupakan komplikasi yang paling sering terjadi $(35,1 \%)$. Lebih dari $70 \%$ penderita diabetes melitus juga menderita tekanan darah tinggi. ${ }^{24}$ Diabetes melitus bersama dengan hipertensi akan meningkatkan risiko komplikasi mikrovaskular dan makrovaskular. Peningkatan $10 \mathrm{mmHg}$ sistolik berhubungan dengan peningkatan $12 \%$ setiap komplikasi diabetes, $15 \%$ kematian berhubungan dengan diabetes, $11 \%$ peningkatan infark miokardial, dan $13 \%$ peningkatan komplikasi mikrovaskular diabetes melitus. Kematian akibat penyakit jantung dua sampai empat kali lebih tinggi pada penderita diabetes melitus dibandingkan yang non diabetes. Penyandang diabetes 2 berisiko sekitar empat kali lebih besar untuk berkembang menjadi stroke. ${ }^{24}$ Oleh sebab itu, penyandang diabetes yang disertai hipertensi harus lebih menjaga kesehatan menghindari penyakit kronis lain akibat kondisi ini.

Menderita berbagai penyakit komplikasi kronis dapat mengakibatkan kualitas hidup lansia yang buruk, lebih lama tinggal di rumah sakit, dapat mengalami komplikasi yang lebih parah pascaoperasi, biaya perawatan dan mortalitas yang lebih tinggi. ${ }^{5}$ Diabetes dapat diperparah oleh kondisi depresi penderita yang akan semakin memperburuk kondisi penyakit dan mengarah pada keparahan bahkan kematian. ${ }^{25}$ Selain itu, kondisi komplikasi kronis akan mengarahkan kepada penggunaan obat secara bersamaan dalam jumlah yang banyak. Petugas kesehatan dan keluarga lansia harus lebih cermat dalam melakukan pengobatan tersebut sehubungan dengan interaksi obat yang meningkat, kondisi fisik lansia yang menurun untuk mencerna obat, serta obat-obatan yang mempunyai efek yang berlawanan ataupun obat-obatan yang menguatkan apabila dikonsumsi bersamaan. Hal ini berguna untuk mencegah pengobatan yang dapat mengakibatkan efek fatal bahkan kematian pada penyandang. Oleh sebab itu, pencegahan merupakan upaya terbaik karena pengobatan terhadap suatu kesakitan yang banyak dalam waktu yang bersamaan adalah suatu yang kompleks dan mahal.

Pada populasi, diperkirakan perempuan penyandang diabetes melitus dengan status obesitas berisiko 1,3 kali lebih besar untuk mengalami komplikasi daripada lansia penyandang diabetes melitus non obesitas. Diperkirakan pengaruh olahraga atau aktivitas fisik terhadap komplikasi diabetes melitus berkisar cukup besar sekitar dua kali daripada lansia yang tidak cukup aktivitas fisik. Lansia penyandang diabetes melitus yang merokok berisiko 2,48 kali mengalami komplikasi dibandingkan tidak merokok.

\section{Kesimpulan}

Lansia pengidap diabetes melitus yang mengalami komplikasi adalah sekitar $73,1 \%$. Sekitar $41,8 \%$ 
lansia dengan satu penyakit komplikasi, sekitar $24,5 \%$ lansia dengan dua penyakit komplikasi, sekitar 6\% lansia dengan tiga penyakit komplikasi dan sekitar $0,7 \%$ mengidap 4 penyakit komplikasi. Berdasarkan hasil analisis multivariat, diperoleh informasi bahwa faktor-faktor yang mempengaruhi komplikasi diabetes melitus adalah merokok, umur, jenis kelamin, status obesitas, dan aktivitas fisik. Faktor yang paling dominan terhadap status komplikasi diabetes melitus pada lansia adalah status merokok dengan nilai OR yaitu 2,477 . Terdapat interaksi antara jenis kelamin dan status merokok. Lansia perempuan yang berstatus perokok beresiko lebih besar untuk mengalami komplikasi diabetes melitus dibandingkan lansia lakilaki yang berstatus perokok.

\section{Saran}

Cara terbaik untuk meningkatkan kualitas hidup lansia di masa mendatang adalah melalui perilaku yang mendukung kesehatan seperti menjaga status gizi, pengaturan makanan yang baik, mengurangi konsumsi lemak jenuh, cukup aktivitas fisik, cukup konsumsi serat, dan tidak merokok. Kementerian Kesehatan Republik Indonesia sudah mempunyai program CERDIK untuk pencegahan diabetes dan komplikasinya meliputi cek kondisi kesehatan secara berkala, enyahkan asap rokok, rajin aktivitas fisik, diet sehat kalori seimbang, istirahat yang cukup, dan kendalikan stres, perlu penggalakkan dan promosi program kementerian kesehatan. Sistem pengobatan khusus lansia sebaiknya mengintegrasikan dokter, pemberi resep, bagian farmasi, dan pasien.

\section{Ucapan Terima Kasih}

Peneliti mengucapkan terima kasih atas bantuan Badan Penelitian dan Pengembangan Kesehatan Kementerian Kesehatan dalam memperoleh data sekunder Riskesdas 2007.

\section{Daftar Pustaka}

1. Mobbs C. Biology of aging. In: Berkow R, Beers MH, editors. The merck manual of geriatrics [monograph on internet]. Whitehouse station, NJ, USA: Merck \& Co. Inc; 2001 [cited 2012 Sept 30]. Available from: http://www.merck.com/pubs/mm_geriatrics/sec1/ch1.html.

2. Pradono J. Transisi epidemiologi di Indonesia. Pertemuan Rapat Koordinasi Nasional Penelitian dan Pengembangan Kesehatan Bandung, 24-26 Agustus 2005. Bandung: Penelitian dan Pengembangan Kesehatan; 2005.

3. World Health Organization. Global health and aging. Geneva: World Health Organization; 2011.

4. Kementerian Kesehatan Republik Indonesia. Panduan peringatan hari kesehatan sedunia: Kesehatan yang baik memperpanjang usia kehidupan. Jakarta: Pusat Intelejensia Kesehatan Pusat Promosi Kesehatan Kementrian Kesehatan Republik Indonesia; 2012.
5. Khanam MA, Streatfield PK, Kabir ZN, Qiu C, Cornelius C, Wahlin A. Prevalence and patterns of multimorbidity among elderly people in rural Bangladesh: a cross-sectional study. Journal of Health Population and Nutrition. 2011; 29 (4): 406-14.

6. Marengoni A, Winblad B, Karp A, Fratiglioni L. Prevalence of chronic diseases and multimorbidity among the elderly population in Sweden. American Journal of Public Health. 2008; 98 (7): 1198-200.

7. Rully. Fasilitas dan pelayanan kesehatan lansia di rumah sakit umum dalam perspektif hak asasi manusia [diakses tanggal 20 September 2013]. Diunduh dalam: http://www.balitbangham.go.id/JURNAL/ Jurnal HAM I RULLY.pdf.

8. Corwin EJ. Buku saku patofisiologi. 3rd ed. Jakarta: Penerbit Kedokteran EGC; 2009.

9. Deshpande AD, Hayes MH, Schootman M. Epidemiology of diabetes and diabetes-related complications. Physical Therapy. 2008; 88 (11): 1254-64.

10. Martini D. Faktor-faktor yang berhubungan dengan kejadian komplikasi pada penyandang diabetes di Klub Persadia Rumah Sakit Islam Pondok Kopi Jakarta Timur 1998-2005 [skripsi]. Depok: Universitas Indonesia; 2005.

11. Sclater A. Diabetes in the elderly: the geritrician's perspective. Canadian Journal of Diabetes. 2003; 27 (2): 172-5.

12. Kurniawan I. Diabetes Tipe 2 pada usia lanjut. Majalah Kedokteran Indonesia. 2010; 60 (12).

13. Maisaroh S. Karakteristik penyandang diabetes melitus dan beberapa faktor yang berhubungan dengan komplikasi pada penyandang yang dirawat inap di RSUD dr. H. Abdul Moeloek Provinsi Lampung tahun 2000-2002 [skripsi]. Depok: Universitas Indonesia; 2003.

14. Sopriana R. Prevalensi dan determinan diabetes di poli lansia Puskesmas Kecamatan Jatinegara, Jakarta Timur Tahun 2011 [skripsi]. Depok: Universitas Indonesia; 2011.

15. Onggo IT. Lima penyakit utama pencabut nyawa. 1st ed. Yogyakarta: Mitra Buku; 2011.

16. Martini. Beberapa faktor yang berhubungan dengan terjadinya komplikasi pada penyandang diabetes melitus tidak tergantung insulin (DMTT-I) di Unit Rawat Inap RSUD Pasar Rebo Jakarta Timur tahun 2001 [skripsi]. Depok: Universitas Indonesia; 2001.

17. Boyd CM, Fortin M. Future of multimorbidity research: how should understanding of multimorbidity inform health system design? Public Health Reviews. 2010; 32: 451-74.

18. Caspersen CJ, Beckles GI, Albright AL. Aging, diabetes, and the public health system in the United States. American Journal of Public Health. 2012; 102 (8): 148-97.

19. Klaukka T. Multiuse of medicines in Finland. Medical Care [serial on the internet]. 1993; 31 (5): 445-50 [cited 2010 Feb 15]. Available from: http://www.researchgate.net/publication/14697310_Multiuse_of_medicine_in_Finland.

20. Offerhaus L. Drugs for the elderly. 2nd Edition European Series Number 71. Copenhagen: World Health Organization Regional Publication; 2007.

21. Trihandini I. Potret buram pelayanan kesehatan lanjut usia di Indonesia. Jurnal Kesehatan Masyarakat Nasional (Kesmas). 2007; 1 (5): 226-31.

22. Kompas Cyber Media. Kelompok lansia belum terurus [diakses tanggal 4 Februari 2012]. Diunduh dalam: http://nasional.kompas.com/read/- 
2012/02/04/04011737/Kelompok.Lansia.Belum.Terurus.

23. Meeuwisse-Pasterkamp SH, van der Klauw MM, Wolfenbuttel B. Type 2 diabetes mellitus: prevention of macrovaskular complications. Expert Review Cardiovascular Therapy. 2008; 6 (3): 323-41.

24. Meneilly GS, Tessier D. Diabetes in the elderly. In: Morley JE, Van den
Berg L, editors. Contemporary endorinology, endorinology of ageing. Totowa, NJ: Humana Press; 2000 .p. 181-203

25. Rosenthal MJ, Fajardo M, Gilmore S, Morley JE, Naliboff BD. Hospitalization and mortality of diabetes in older adults. Diabetes Care 1998; 21: 231-5. 